\title{
Selection Criteria for a Tobacco Curing Solar Thermal Collector Energy System in Zimbabwe
}

\section{Criterios de selección de un sistema de energía solar térmica para el curado del tabaco en Zimbabue}

DOI: $10.46932 /$ sfjdv2n3-016

Received in: May 1st, 2021

Accepted in: Jun 30th, 2021

\section{Nelson Shati}

PhD student with the Mechanical Engineering Department at the University of Zimbabwe. He earned B.S. in Electrical Engineering from Tianjin University, China, Master of Business Administration from University of Zimbabwe, and Master of Science in Engineering Management from Brunel University London, United Kingdom. He is a budding publisher of journal and conference papers with research interests in renewable energy, manufacturing and maintenance management.

Department of Mechanical Engineering

University of Zimbabwe

P. O. Box MP167, Mount Pleasant, Harare, Zimbabwe

E-mail: nshati1965@gmail.com, ignatiomadanhire@gmail.com

\section{Ignatio Madanhire}

DPhil in Engineering Management majoring in Cleaner Production and Waste Management from the University of Johannesburg. He is part of the lecturing team at the University of Zimbabwe in Mechanical Department. He is a member of Zimbabwe Institute of Engineers (ZIE) and is a registered engineer with the Engineering Council of Zimbabwe (ECZ). He has a passion for academic research work in pursuit of insights on effective waste symbiotic solutions in industrial operations and industrial sustainability.

\section{Emmanuel Mashonjowa}

Professor of Physics at the University of Zimbabwe, has worked on greenhouse design and climate control for greenhouse rose production in Zimbabwe. He is passionate researcher on environmental sustainability issues.

University of Zimbabwe

P. O. Box MP167, Mount Pleasant, Harare, Zimbabwe

E-mail: emashonjowa@gmail.com

\begin{abstract}
The main objective of the current paper is to select an appropriate tobacco curing solar thermal collector. Tobacco is the second largest foreign currency earner after gold in Zimbabwe. The crop's post-harvest activities have adverse effects through application of fossil fuels especially firewood. Firewood and coal burning have negative consequences of increasing the greenhouse effects, air pollution, high levels of deforestation causing subsequent land degradation and soil nutrients depletion. Small-scale tobacco farmers are economically disempowered and resort to use firewood as the main tobacco curing fuel source. In embracing modern trends of going green, introducing solar thermal technology in Zimbabwe becomes a prerequisite. In a survey conducted among small-scale tobacco farmers in July 2020, majority of them unanimously accepted a paradigm shift towards sustainability through adopting tobacco curing solar technologies. The system should be robust, reliable, durable, affordable and sustainable for farmers to have usage confidence and guaranteeing uninterrupted performance as tobacco is temperature and
\end{abstract}


humidity sensitive. The main energy generation component is the solar thermal collector with solar photovoltaic supplying the system's electricity needs. The paper develops solar technology selection criteria through literature review. Selection made upon reviewing all the factors is the solar thermal air flat-plate collector.

Keywords: Flat plate collector, irradiation, solar air collector, solar water collector, tobacco curing

\section{INTRODUCTION}

Worldwide research carried out on renewable energy (RE) resources and systems in the last decades proved that RE conversion systems are cost effective (Kalogirou, 2004). Nowadays, concern for the environment is present in the lives of a large part of the population (Martelli, 2020). Due to anthropogenic actions the concentration of greenhouse gases (GHG) has been increasing and boosting the global temperature of the planet (Martelli, 2020). Increased greenhouse gases through fossil fuel use add to heat trapped or reduce heat radiated from the earth's surface, raising its temperature (Kalogirou, 2004). RE systems decrease environmental pollution by substituting electricity and conventional fuels (Kalogirou, 2004). A farmer maximizes available energy resources by distribution optimisation among different consumers including solar dryers (Al-Neama and Farkas (2018). An integrated farm solar energy system is designed without redundancy by provision of hot water for use. Designed solar air dryers use lower temperature for space heating. Medium and higher temperature solar heaters use liquid collectors. Crop drying systems employing motorized fans and/or electrical heating are inappropriate in many rural locations of most developing countries (Echukwu and Norton, 1999). Solar photovoltaics electrically now support solar thermal drying fans and controls. The paper uses collector and climate literature review to develop a tobacco curing solar thermal technology.

\section{BACKGROUND}

Worldwide fossil fuels' rapid depletion necessitated an urgent search for alternative energy sources for current demand (Zhou et al, 2010). Reduction in fossil fuels' reliance is due to the global warming phenomena raising imperatives to fulfil energy demand whilst minimizing negative environmental impacts (Zhou et al, 2010). Tobacco curing requires energy consumption reduction through identification of energy-improving technologies (Musoni et al, 2013). Solar thermal fulfils substantial amount of heat demand in industrial and agricultural processes within any country (IEA-ETSAP and IRENA, 2015). Main resources for future sustainable energy systems will be renewables with solar thermal as a key contributor (Faninger, 2010). Solar radiation is an abundant zero-carbon energy source (Saini et al, 2018). It is a 
clean and emission-free renewable energy source without pollutants harmful to nature (Kesraoui et al, 2016).

\section{TOBACCO LEAF FLUE-CURING SYSTEM}

Tobacco leaf flue-curing consumes large amounts of energy demanding efficiency and environment friendly heating approach (Cao et al, 2017). Applicable temperature and moisture removal energy are important parameters (Farkas, 2013). Tobacco curing involves controlling temperature, humidity and ventilation (Musoni et al, 2013). Figure 1 shows the tobacco curing process with yellowing stage taking place at a $40^{\circ} \mathrm{C}$ and 85 percent humidity. Most wilting occurs from $40^{\circ} \mathrm{C}$ to $48^{\circ} \mathrm{C}$ dry-bulb temperature and tobacco loosens considerably with air moving through. When prime yellowed tobacco leaves are wilted, leaf drying begins. With curing over and stems killed the moisture content is near zero. Leaves and stems become brittle and moisture is added restoring it to 15 percent for easy crop handling (Sumner et al, 2009).

Figure 1: Bulk curing schedule for mature, ripe tobacco (Sumner et al, 2009)

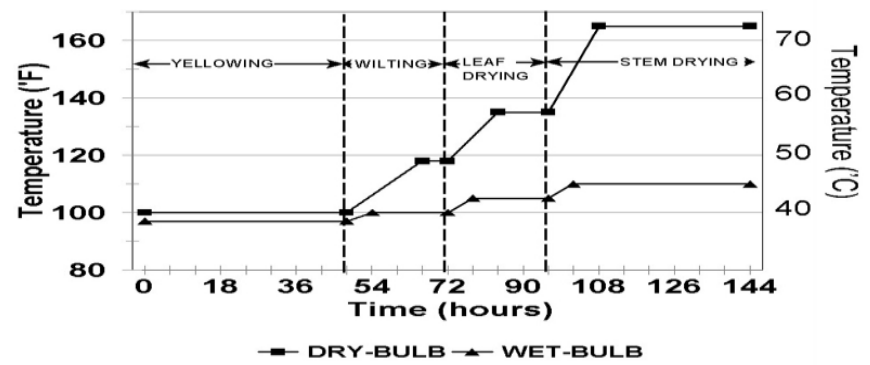

\section{METHODOLOGY: LITERATURE REVIEW OF SOLAR COLLECTOR TECHNOLOGY AND DEMAND SITE RESOURCES}

The adopted methodology is literature review for various types of solar thermal collectors. The state of the art also dwells on solar and water resources availability in Zimbabwe's five agro-ecological farming regions. Literature review builds up criteria for selecting the best option solar collector suitable for the Zimbabwean environment. Various solar thermal energy harvesting techniques apply solar radiation incident on the optical area (Saini et al, 2018). Solar collectors are special devices made with shapes based on usage to absorb and transfer solar energy into usable or storable form (Mohseni-Languri et al, 2009). Solar energy conversion is done through the stationary collector, sun tracking concentrating and photovoltaic panel (Kesraoui et al, 2016).

\subsection{CHARACTERISTICS OF SOLAR COLLECTOR TYPES}


Solar heating technologies collect thermal energy from the sun and use this heat for drying purposes, space heating, cooling and providing process heat (IEA-ETSAP and IRENA, 2015). Three groups of solar thermal technologies useful for industrial processes heat are solar air collectors, solar water systems and solar concentrators (IEA-ETSAP and IRENA, 2015). Kalogirou (2003) describes three major groups of solar collectors as being two-axes tracking, single-axis tracking and stationary collectors. Twoaxes tracking collectors comprise of parabolic dish reflector (PDR) and heliostat field collector (HFC) with application temperatures from $100^{\circ} \mathrm{C}$ to $2000^{\circ} \mathrm{C}$ unsuitable for tobacco curing. Single axis-tracking are Fresnel lenses collector (FLC), parabolic trough collector (PTC) and cylindrical trough collector (CTC) with temperatures from $60^{\circ} \mathrm{C}$ to $300^{\circ} \mathrm{C}$ yet tobacco curing begins at $35^{\circ} \mathrm{C}$. Stationary collectors are evacuated tube collector (ETC), compound parabolic collector (CPC) and flat-plate collector (FPC). Temperatures for the ETC and CPC are between $50^{\circ} \mathrm{C}$ and $200^{\circ} \mathrm{C}$ with $50^{\circ} \mathrm{C}$ being an intermediate stage of tobacco curing. FPCs range from $30^{\circ} \mathrm{C}$ to $80^{\circ} \mathrm{C}$ fulfilling tobacco curing temperatures. FPCs are usually permanently fixed in position and require no sun-tracking and they are oriented towards the equator, facing south in the northern hemisphere and north in the southern hemisphere (Kalogirou, 2003). Collector optimum limit tilt angle should equal the location latitude with angle variation of $10^{\circ}$ and $15^{\circ}$ depending on the application.

\subsection{FLAT PLATE COLLECTORS}

Solar FPCs are the most common types of collectors used as solar hot water or solar air heaters in domestic or industrial heating, ventilation and air conditioning systems (Mohseni-Languri et al, 2009). Figure 2 is a schematic view of an FPC comprising of glazing, tubes, fins or passages, absorber plate, headers or manifolds, insulation and container or casing with well insulated underside and sides to reduce conduction losses (Kalogirou, 2004).

Figure 2: View of a solar flat-plate collector (Kalogirou, 2014)

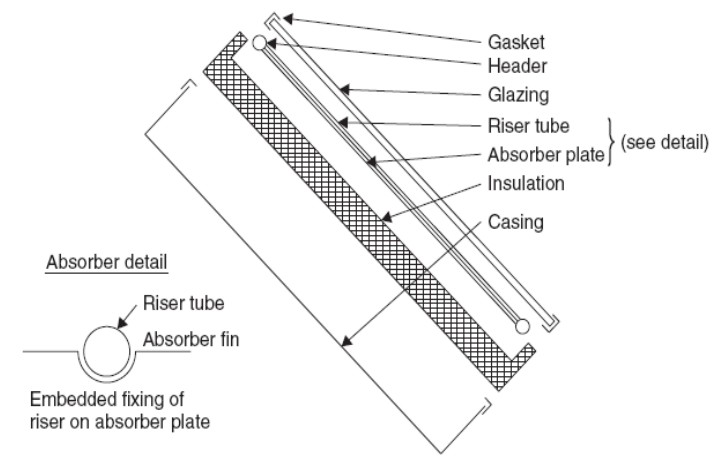


Glazing or cover plate is made up of glass sheets or other diathermanous or radiation-transmitting material. Glass transmits up to 90 percent of the incoming shortwave solar irradiation and virtually none of the longwave radiation emitted outward by the absorber plate because longwave radiation increases glass temperature heat losses to the surrounding atmosphere by radiation and convection (Kalogirou, 2004). Glazing is the most important part of the solar heater as it transmits the maximum amount radiation to the absorbing plate, reduces the heat losses to the atmosphere from the absorbing plate and serves as a protective shield (Saini et al, 2018). Important characteristics are durability, energy transmission, nondegradability and strength (Saini et al, 2018). Rigidity, lightweight, resistance to breaking and minimal costs are benefits of using plastic materials for cover plate but they have a disadvantage of lifespan reduction due to impact of ultraviolet rays which blur transmissivity (Saini et al, 2018).

The absorber is a flat-plate made of conductive materials which have high thermal conductivity, better tensile strength, and non-corrosiveness such as copper or aluminium which acts as a heat exchanger by transmitting acquired heat into the fluid and it is insulated on non-flow sides (Saini et al, 2018). A heat exchanger is a device or system in which heat is transferred from one fluid to another (Kreith et al, 2011). Energy proportion of the solar radiation converted into heat inside the absorber is partly transported to the heat carrier flowing through channels within absorber by heat transfer (Syafaruddin and Hiyama, 2020). Absorbers are sometimes corrugated or grooved plates integral with the tubes, headers or manifolds admit and discharge the fluid. The collector plate absorbs as much irradiation as possible through the glazing, while losing as little heat as possible upward to the to the atmosphere through reflection and convection as well as downward conduction through the insulated back of the casing (Kalogirou, 2004). An energy efficient solar collector should absorb incident radiation, convert it to thermal energy to a heat transfer medium with minimum losses at each step (Kalogirou, 2004). Thermal insulation creates a barrier between warm air inside and cold air outside and vice versa (Khan and Hassan, 2016). Solar collector insulation is a simple and effective way of retaining heat, particularly at night (Saint et al, 2018). A large percentage of heat is lost through the glazing which needs to be exposed to gain solar irradiance. Insulation prevents conduction or convection heat losses on absorbing plates. Most used insulation which provides best heat resistance is glass wool filled under the absorbing plate and sides (Saint et al, 2018). The container or casing surrounds the collector and protects it from dust, moisture and damage from other hazards (Kalogirou, 2004).

\subsection{PRINCIPLES OF SOLAR ENERGY CONVERSION PROCESS IN A SOLAR COLLECTOR}

Figure 3 shows the principles of conversion from solar energy into usable heat energy. The most important parameter playing a primary role for using a solar heating system is irradiance. Thermal 
radiation is defined as the radiant energy emitted by a medium by virtue of its temperature and the term irradiation denotes the radiation incident from all directions (Kreith et al, 2011). The solar irradiance is a power of the sun in the form of electromagnetic waves per unit area on the earth's surface and it is measured in kilowatts per square metre, $\mathrm{kW} / \mathrm{m}^{2}$ (Dehgan and Pfeiffer, 2017). When solar radiation passes through a transparent cover and impinges on the blackened absorber surface of high absorptivity, a large portion of this energy is absorbed and then transferred to the transport medium in the fluid tubes to be carried away for storage and use.

Figure 3: Energy conversion chain from solar irradiation to heat energy (Syafaruddin et al, 2020)

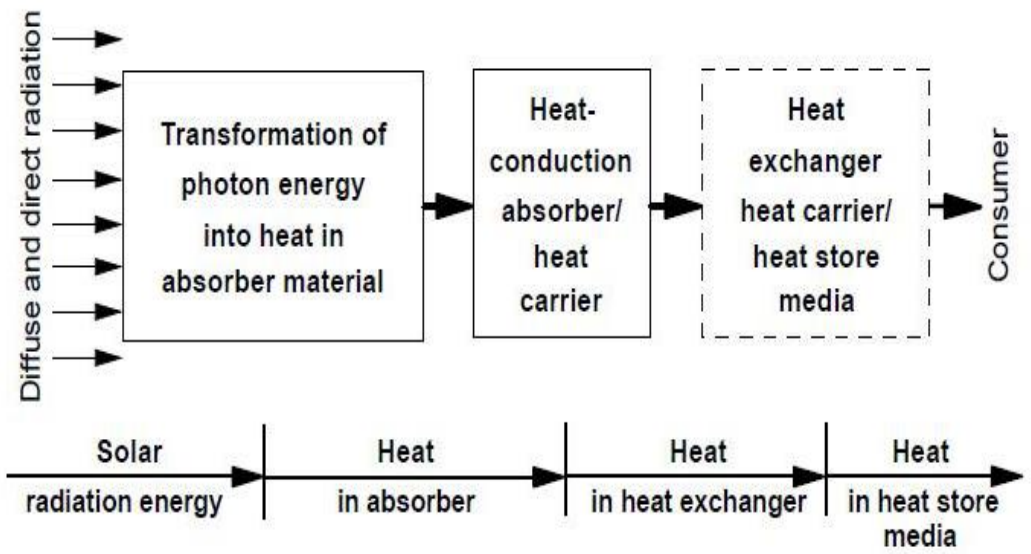

\subsection{SOLAR WATER THERMAL COLLECTOR}

Figure 4 shows a solar space heating and hot water system with water as the heat transfer fluid for non-freeze climates like in Zimbabwe. Kalogirou (2014) cites that control of the solar heating system is based on two thermostats namely the collector storage differential thermostat and the room temperature. When the room temperature senses a low temperature, the load pump is activated, drawing heated water from the main storage tank to meet demand. If the energy stored in the tank cannot meet load demand, the thermostat activates the auxiliary heater to supply the heating requirements balance. The controller operates the three-way valves so that the flow is through the auxiliary heater whenever the storage tank is depleted. Duffie and Beckman (2013) cite that the load heat exchanger transfers energy from the tank to the heated spaces as extraction of energy for service hot water occurs. Auxiliary energy for heating is added to top off that available from the solar energy system. When a water based solar energy system is used in conjunction with a warm-air space-heating system, the most economical means of auxiliary energy supply is by use of a fossil-fired boiler for the latter to take over the entire heating load in bad weather (Kalogirou, 2014). The load heat exchanger for transferring solar heat from the storage tank to the building air must be adequately designed to avoid excessive temperature drop and subsequent tank and collector temperature increase (Duffie and Beckman, 2013). 
Figure 4: Schematic diagram of a solar space heating and hot water system (Kaligorou, 2014)

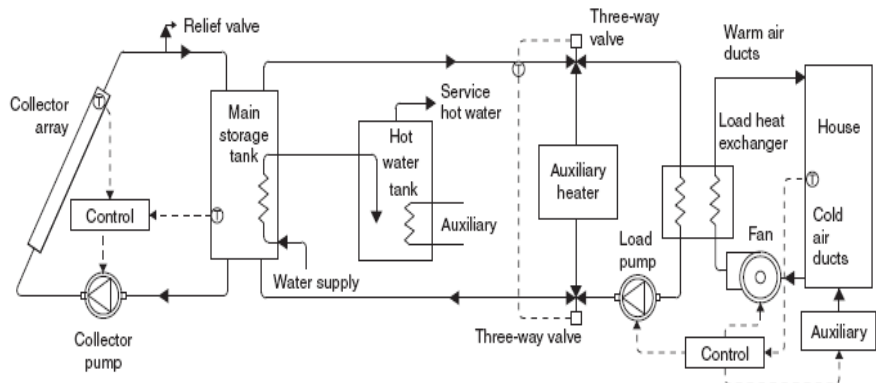

Solar water thermal systems main drawbacks are their sophisticated circuits such as boilers, antifreeze tanks, pumps relief valves and complex controls. United Nations Development Programme, (UNDP, 2017) recommends hot water supply from a solar water heating system to be at a minimum temperature of $60^{\circ} \mathrm{C}$. This prevents creating a favourable environment for legionnaires bacteria found in water, surviving below $60^{\circ} \mathrm{C}$ and thriving at lukewarm water temperatures between 25 and $42^{\circ} \mathrm{C}$ with an optimum temperature of $35^{\circ} \mathrm{C}$ within tobacco curing. When designing a solar thermal water heating system, considerations should be made of legionnaires' disease, a severe pneumonia whose outbreak affected a meeting of American Legion in 1976 (Firebird, 2020). Protection against legionella is by maintaining water temperature above $60^{\circ} \mathrm{C}$, making frequent water circulation, system sterilization on premises left vacant for some time and flushing out water systems on regular basis to prevent water stagnation (Firebird, 2020).

\subsection{SOLAR THERMAL AIR COLLECTOR}

Being an excellent example of thermal application, the solar air heater is a system which collects solar radiation and exchanges heat gathered with moving air (Saini et al, 2018). During the electromagnetic radiation, the irradiations from the sun get rapidly absorbed by the thin sheet of aluminium or copper and this heat is then transferred to the air to raise its temperature. Some of the heat is lost through convections, radiation conduction and reflection. Useful air is transmitted to the consumer. Figure 5 is a schematic diagram of a basic solar air heating system with a pebble bed storage unit and an auxiliary heating source. Varying operational modes are achieved by the use of dampers. In air systems it is not practical to have simultaneous addition and removal of energy from the storage. If the energy supplied from the collector or storage is inadequate to meet the load, the auxiliary energy can be used to top up the air temperature to cover the building load. It is also possible to bypass the collector and storage unit when there is no sunshine and the storage tank is completely depleted and the auxiliary source solely delivers the required thermal energy (Kalogirou, 2014). 
Figure 5: Schematic of basic solar air system (Kalogirou, 2014)

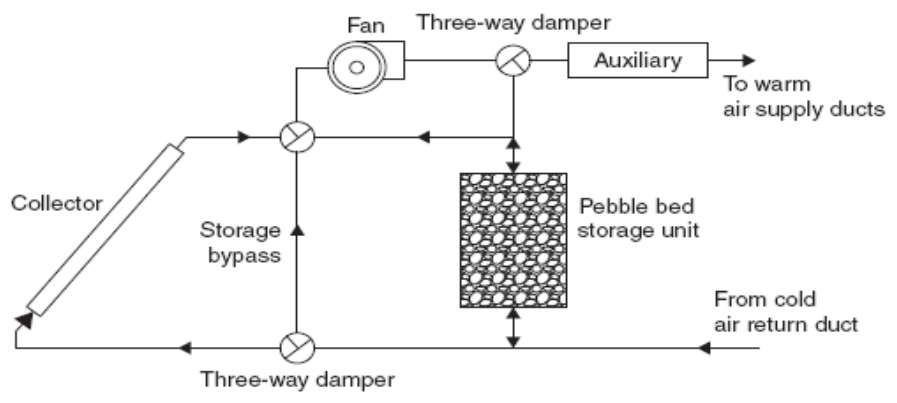

The advantage of air heat transfer fluid is the degree of stratification in the pebble bed leading to lower collector inlet temperatures (Kalogirou (2014). The working fluid is air with warm air-heating systems and control equipment common in building services industry. Air does not need freezing or boiling protection, it is non-corrosive, air does not suffer from heat transfer fluid degradation and it is free. Solar air-based system is more cost effective because no safety valves or expansion vessels are required (Kalogirou, 2014). Limitations are higher storage costs, noise operation, lower fluid capacitance rates, low air flow rates leading to lower FR values than the liquid-heating collectors, hence reduced collector performance. Air handling equipment such as ducts and fans requires more space than piping and pumps, difficulty to detect air leaks and more parasitic power consumption of fan-driving electricity than liquid systems (Kalogirou, 2014).

\subsection{RESOURCE AVAILABILITY}

In developing an energy system for a specific site, it is essential to know that particular place's energy demand and available resources, thus, calling for energy planners to study the solar, wind and other potential resources available in addition to energy demand (Mussa et al, 2015). Based on annual mean sunshine period and wind speed, the most suitable components and installation costs for a solarwind system at a remote region in Turkey were determined (Oguz and Ozsoy, 2015). Solar thermal uses global horizontal radiation made up of direct beam and diffuse radiation. Figure 6 shows the average global horizontal radiation map for Zimbabwe in $\mathrm{kWh} / \mathrm{m}^{2} /$ day (World Bank, 2019). Tobacco farming is largely concentrated in the north-western, northern and north-eastern areas of the country which the radiation scale index shows an average daily irradiance of ranging from 5.5 to $6.1 \mathrm{kWh} / \mathrm{m}^{2} /$ day. Though irradiations vary from place to place and time to time daily, the map shows that the solar intensity is suitable for installing solar thermal technologies in Zimbabwe's major tobacco growing regions. Table 1 from GAISMA shows Harare with monthly average insolation between $4.36 \mathrm{kWh} / \mathrm{m}^{2} /$ day and 6.49 $\mathrm{kWh} / \mathrm{m}^{2} /$ day and clearness index between 0.49 and 0.67 both suitable for solar thermal installations. 
Figure 6: Map of Global Horizontal Irradiation in Zimbabwe (World Bank, 2019)

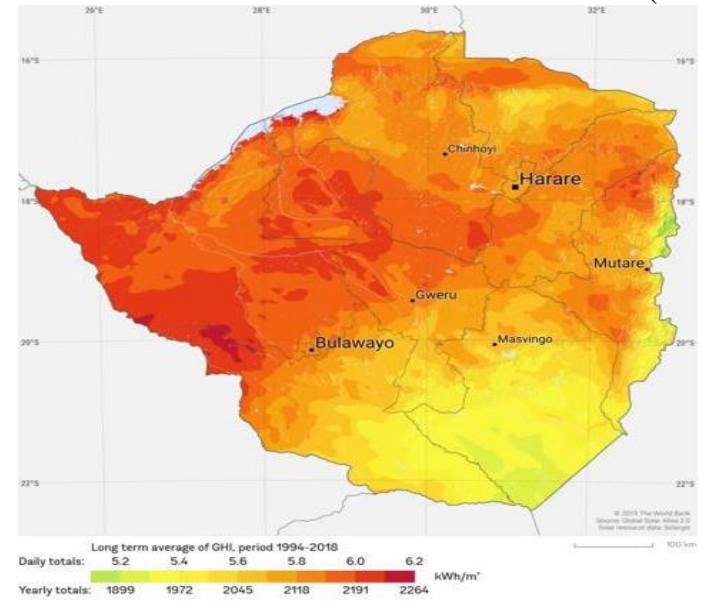

Table 1: Harare-Zimbabwe Solar energy and surface meteorology https://www.gaisma.com/en/location/harare.html)

\begin{tabular}{|l|l|l|l|l|l|l|l|l|l|l|l|l|}
\hline Variable & $\mathbf{J}$ & $\mathbf{F}$ & $\mathbf{M}$ & $\mathbf{A}$ & $\mathbf{M}$ & $\mathbf{J}$ & $\mathbf{J}$ & $\mathbf{A}$ & $\mathbf{S}$ & $\mathbf{O}$ & $\mathbf{N}$ & $\mathbf{D}$ \\
\hline Insolation, $\mathbf{k W h} / \mathbf{m}^{\mathbf{2}} / \mathbf{d a y}$ & 5.64 & 5.56 & 5.38 & 5.18 & 4.79 & 4.36 & 4.65 & 5.43 & 6.38 & 6.49 & 6.13 & 5.57 \\
\hline Clearness, $\mathbf{0}-\mathbf{1}$ & 0.49 & 0.50 & 0.53 & 0.58 & 0.62 & 0.62 & 0.64 & 0.66 & 0.67 & 0.61 & 0.55 & 0.49 \\
\hline Temperature, ${ }^{\circ} \mathbf{C}$ & 22.20 & 21.90 & 21.66 & 20.46 & 18.46 & 16.31 & 16.21 & 18.63 & 22.28 & 23.69 & 23.52 & 22.16 \\
\hline Wind speed, m/s & 4.30 & 4.14 & 4.21 & 3.96 & 3.83 & 3.96 & 4.16 & 4.63 & 5.33 & 5.65 & 5.30 & 4.65 \\
\hline Precipitation, mm & 209 & 181 & 116 & 44 & 8 & 2 & 2 & 2 & 6 & 38 & 100 & 179 \\
\hline Wet days, d & 17.4 & 15.1 & 10.7 & 5.7 & 2.0 & 1.0 & 1.0 & 1.0 & 1.2 & 4.7 & 10.9 & 16.2 \\
\hline
\end{tabular}

\subsection{WATER AVAILABILITY}

Figure 7 shows Zimbabwe's five agro-ecological zones (AEZs) or natural regions, NR I, II, III, IV and $\mathrm{V}$ with rainfall regime, soil quality and vegetation declining progressively from NR I to NR V (FAO, 2020). NR I has more than $1000 \mathrm{~mm} /$ year annual rainfall, low temperatures, high altitude and steep slopes in the eastern highlands. Activities are timber, dairy, coffee, tea, bananas, apples, potatoes, peas, vegetables and export flowers (FAO, 2020). NR II in the mid-north of the country has fairly reliable annual rainfall of 750 to $1000 \mathrm{~mm}$ from November to March/April. Reliable rainfall and good soils cause intensive cropping of flue-cured tobacco, maize, cotton, wheat, soybeans, sorghum, groundnuts, seed maize, wheat, barley and burley tobacco. Three quarters of national cropping area and livestock mainly beef, dairy, pig and poultry is in NR II. NR III is in mid-altitude areas of the country with annual rainfall of 500-750 mm, mid-season dry spells, high temperatures ideal for drought-tolerant crops and semiintensive livestock especially beef ranching based on fodder crops. NR IV is in the low-lying areas north and south of the country with annual rainfall of $450-650 \mathrm{~mm}$, severe dry spells during the rainy season, and frequent seasonal droughts, growing drought-tolerant maize varieties, small grains, cattle and wildlife. NR V covers lowland areas less than $900 \mathrm{~m}$ above sea level north and south of the country with highly erratic rainfall of less than $650 \mathrm{~mm} /$ year and suitable for extensive cattle, goat and game-ranching. Major 
factors that affected farming patterns, cropping and water resources in all regions are the agrarian land reform and climate change as briefly described.

Figure 7: Natural regions of Zimbabwe (http://www.fao.org/3/a0395e/a0395e06.htm)

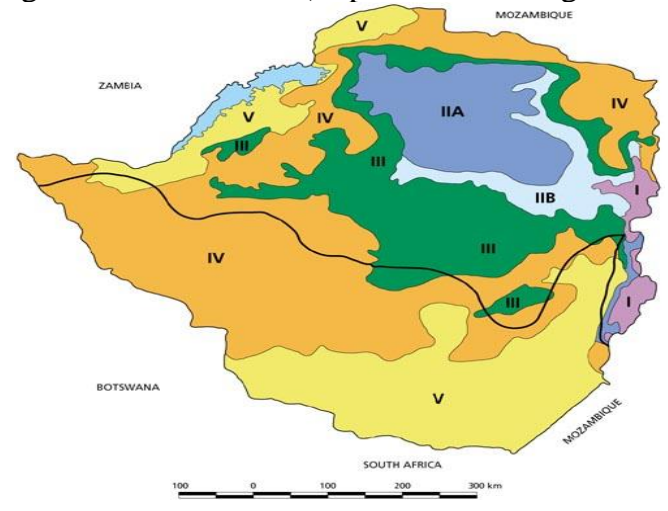

Prior 2000, dominant agricultural subsectors were large-scale commercial and communal lands farming systems. The agrarian land reform of 1999/2000 subdivided most commercial farms through redistribution of land to new farmers by acquisition of 12.4 million out of 16 million hectares from 6796 large-scale farms. New A1 model farmers allocated five arable hectares each and communal grazing land numbered 127192 households and 12943 individuals were allocated new A2 self-contained farming units. Maize dominated across all AEZs occupying 50-70 percent of the cropped area in NRs I, IIA, and IIB, and 40-50 percent of the cropped area in NRs III, IV and V with cotton dominant in NR III (FAO, 2020). Table 2 shows that tobacco transformed the farming landscape in northern Zimbabwe as it now dominates in four provinces of Mashonaland East, Central, West and Manicaland, cutting across all AEZs and ushering in a new set of small-scale tobacco farmers. Numbers of tobacco growers increased exponentially from 29000 in 2009 to 50000 in 2010 and tobacco hectares rose from 42000 to 50000 (TIMB, 2010). Small-scale farmers were enticed by tobacco's attractiveness with high prospects to improve living standards in a depressed economy (Madanhire et al, 2018).

Table 2 Growers and tobacco planted hectarage in 2009 and 2010 (Tobacco Industry and Marketing Board, 2010)

\begin{tabular}{|l|c|c|c|c|c|c|c|c|}
\hline Province & $\begin{array}{c}20099 \\
\mathrm{Ng}\end{array}$ & $\begin{array}{c}2009 \\
\mathrm{IIa}^{*}\end{array}$ & $\begin{array}{c}2010 \\
\mathrm{Ng}\end{array}$ & $\begin{array}{c}2010 \\
\mathrm{IIa}^{*}\end{array}$ & $\begin{array}{c}\text { Incrcase } \\
\mathrm{Ng}\end{array}$ & $\begin{array}{c}\% \text { incrcasc } \\
\mathrm{Ng}\end{array}$ & $\begin{array}{c}\text { incrcasc } \\
\mathrm{IIa}^{*}\end{array}$ & $\begin{array}{c}\% \\
\text { increase }_{\mathrm{Ha}^{*}}\end{array}$ \\
\hline $\begin{array}{l}\text { Mashonaland } \\
\text { East }\end{array}$ & 6132 & 12199 & 10273 & 11690 & 4141 & 68 & -509 & -4 \\
\hline $\begin{array}{l}\text { Mashonaland } \\
\text { West }\end{array}$ & 9534 & 6770 & 15276 & 17991 & 5742 & 60 & 11221 & 62.3 \\
\hline Masvingo & 13 & 18 & 31 & 50 & 18 & 138 & 32 & 179 \\
\hline $\begin{array}{l}\text { Mashonaland } \\
\text { Central }\end{array}$ & 7698 & 14053 & 13873 & 11155 & 6175 & 80 & -2898 & -21 \\
\hline Manicaland & 5777 & 9178 & 9400 & 9556 & 3623 & 63 & 378 & 4 \\
\hline Totals & 29154 & 42218 & 48853 & 50442 & 19699 & 409 & 8224 & 19 \\
\hline Average & 5831 & 8444 & 9771 & 10088 & 3940 & 82 & 1645 & 19 \\
\hline
\end{tabular}

Note: $\mathrm{Ng}$ indicates number of growers and $\mathrm{Ha}^{*}$ is the hectares under tobacco crop 
Figure 8 shows tobacco related deforestation which is five percent annually in Africa and 12 percent in Southern Africa (Manyanhaire and Kurangwa, 2014). Zimbabwe's tobacco related deforestation caused a loss of 60000 hectares in 2017 (Kafe, 2019). Figure 9 shows a barn razed by curing related naked fires inducing more environmental degradation, air pollution and deforestation by reconstruction. Zimbabwe is semi-arid with limited and unreliable rainfall patterns and temperature variations and climatic changes have created more arid agricultural environments, shifting AEZs or NRs (Brown et al, 2012). Chinhoyi, Chibero and environs have moved from NR II to NR III while Kwekwe and surroundings moved from NR III to NR IV, NR I reduced in size, NR II moved further east and NR III moved further north (Brown et al, 2012).

Figure 8: Massive deforestation caused by tobacco curing tree felling (Abilla, 2006)

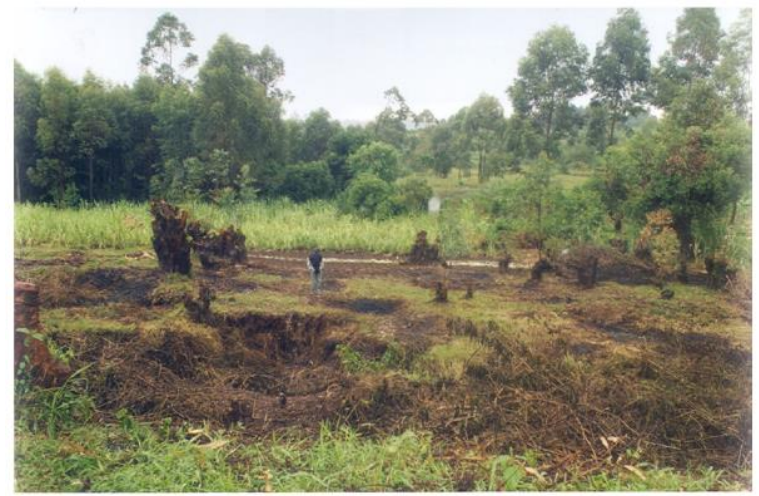

University of Zimbabwe's Department of Geography and Environmental Science developed best and worst case regional climate change scenarios showing an increase in warming trends, rainfall variability, water stress and rise in vulnerability of communal agricultural land. Water stress will adversely impact on public health, water availability, forestry, biodiversity, rangelands, human settlements and tourism (Murwira, unpublished; Murwira et al., unpublished). Mapfumo et al, (2010) confirmed that most farmers in NR II Hwedza District were aware of climate change in their localities as they observed shifting trends in weather patterns, changing rainfall distributions, increased drought incidences and unpredictable wind movements and cyclones. Seasonal temperature regime changes cause very hot summers and very cold winters, prolonged winter seasons, marked delays in onset of rainy seasons, alternating floods and droughts within same seasons, wetlands disappearance and declining water reservoirs, deforestation and poor farming practices destroying soil and water resources. 
Figure 9: Inspection of a burnt down tobacco barn due to a tobacco curing induced fire (Abilla, 2006)

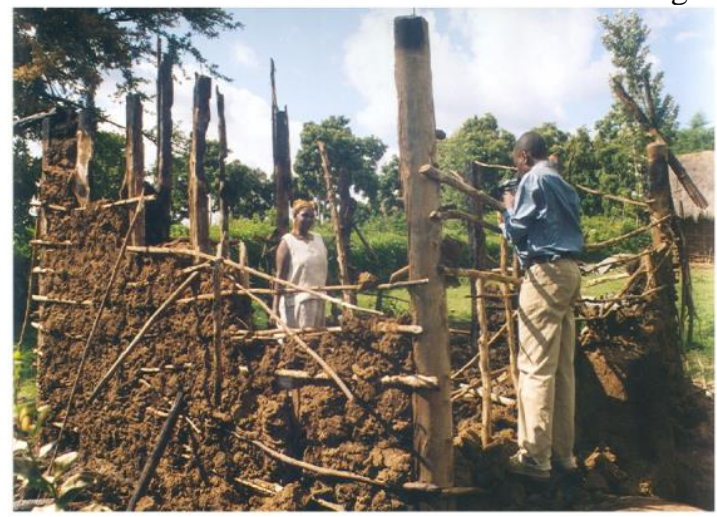

Brown et al (2012) cite climate change vulnerability of women due to increased agricultural workload, shortage of safe, clean drinking water, gendered division of household labour, extra time and exposure to violence and sexual abuse when travelling greater distances to collect water from alternative sources, which may be unclean or unsafe. Vulnerable sectors were urged to optimize rain feeding, adopt improved short-season seed varieties, efficiently use available moisture, apply irrigation and water harvesting techniques, apply mechanisms for improved use of water impoundments, increase networks of water storage facilities and adopt improved agricultural water use efficiency (Brown et al, 2012).

\section{THERMAL COLLECTOR SELECTION AND RECOMMENDATIONS}

Twin calamities of climate change and deforestation are depleting the water resource in Zimbabwean farming areas. Unpredictable rainfall and erratic droughts lead to depletion of both surface and underground water. Human, animal and plant conflict on the remaining meagre water resource available escalates restricting water usage to vital few basics. People draw water for use from faraway places and both domestic and wild animals die due to lack of pasture and water. Plants and crops including tobacco wilt and die as a result of water scarcity. Farmers are financially disempowered to construct weirs, reservoirs and capital intensive borehole drilling. Solar water thermal equipment is too sophisticated to be understood and operated by most small-scale tobacco farmers with literacy slightly above mere reading and writing. Warm water borne legionnaires presents challenges. Expected economic life of solar technology systems is 20 years of which the water scarcity would have escalated, reducing the solar thermal water collector system to a white elephant. Water has better thermal properties such as specific heat capacity and conductivity than air but the option available in semi-arid areas is air. A solar thermal air collector backed up with an eco-friendly auxiliary heat energy source and solar photovoltaic for drives and controls is strongly recommended. This reduces incidences of tobacco fires, deforestation by less wood usage as top up auxiliary, land degradation and optimizes water usage in competing areas of need. Forests reclamation through establishment of green belts begins. 


\section{CONCLUSION}

Following an in depth analysis of solar collectors, availability of solar energy and water in Zimbabwean AEZs, a solar air thermal collector system is selected in developing a small-scale farmer's tobacco curing energy system. SAC air heater is a solar thermal harvesting technique which have gained tremendous popularity (Saini et al, 2018). System designs would address solar air collectors (SACs) weaknesses through follow up on research done to overcome lower thermal efficiencies and improve SACs performances (Deng et al, 2015). SACs apply in space heating and drying processes due to simple manufacturing and maintenance, freeze resistance and less corrosion compared with solar hot water heating systems (Deng et al, 2015). SACs energy systems will be developed for Zimbabwean tobacco farmers and the world in general.

\section{ACKNOWLEDGEMENTS}

The authors would like to acknowledge the support received from the Royal Academy of Engineering through the Higher Education Partnerships for Sub Saharan Africa (HEP SSA) project at the University of Zimbabwe. 


\section{REFERENCES}

Abilla, R. Tobacco in Kuria District, Kenya: Status, Impacts and Policy Issues, 2006. Available: https://.www.researchgate.net/publication/263178505, September 11, 2020.

Al Neama, M, Farkas, I., Utilisation of Solar Air Collectors for Product's Drying Process, Journal of Scientific and Engineering Research, 5 (2): pp. 40-56, 2018.

Brown, D., Chanakira, R. R., Chatiza, K., Dhliwayo, M., Dodman, D., Masiiwa, M., Muchadenyika, D., Mugabe, P., and Zvigadza, S., Climate change impacts, vulnerability and adaptation in Zimbabwe, Climate Change Working Paper Number 3, International Institute for Environment Development (IIED), London, UK, 2012.

Cao, G., Bao, Y., Wu, C., and Wang, Y., Analysis on efficiency optimisation of tobacco leaf flue-curing process. Procedia Engineering 205, pp. 540-547, Jinan, China, 22 October 2017.

Deghan, M., and Pfeiffer, C., Modelling and Control of Collecting Solar Energy for Heating Houses in Norway, Journal of Sustainable Development of Energy, Water and Environmental Systems, 5 (3) pp. 359-376, 2017.

Deng, J., Yang, X., Yang, M., and Wang, Z., Experimental study of a single-pass flat plate solar air collector with severe dust deposition on the transparent glass cover, Energy Procedia 70, pp. 32-40, 2015.

Duffie, J.A., and Beckman, W.A., Solar Engineering of Thermal Processes, $4^{\text {th }}$ Ed. John Wiley and Sons, 2013.

Echukwu, O.V., and Norton, B., Review of solar-energy drying systems II: an overview of solar drying technology, Energy conversion and management 40, pp. 615-655, 1999.

Faninger, C., The Potential of Solar Thermal Technologies in a Sustainable Energy Future, Results from 32 Years of International $R \& D$ Co-operation, IEA Solar Heating and Cooling Programme, 2010. Available: https://www.iea-shc.org, February 12, 2020.

Farkas, I., INTEGRATED USE OF SOLAR ENERGY FOR CROP DRYING, European Drying Conference, Eurodrying 2011, Palma, Balearic Island, Spain, 26-28 October, 2011, 2013.

Food and Agricultrural Organisation, FAO, Chapter 2: Zimbabwe's natural regions and farming systems, Available: http://www.fao.org/3/a0395e/a0395e06.htm, September 9, 2020.

Firebird, Guide to Solar Thermal Systems Working Towards a Greener Planet, Available: https://www.firebird.uk.com, September 7, 2020.

Gaisma, Harare, Zimbabwe, solar energy and surface meteorology, Available: https://www.gaisma.com/en/location/harare.html, May 21, 2020.

Hassan, N.M.S., and Khan M.M.K., Thermofluid modelling for energy applications, Academic Press, 2016. 
IEA-ETSAP and IRENA, International Energy Agency-Energy Technology Systems Analysis Programme and International Renewable Energy Agency, Solar Heat for Industrial Processes, Technology Brief E21, Available: https://www.irena.org/Publications, February 18, 2020.

Kafe, E., Tobacco killing forests, The Sunday Mail, p S14, 17 February 2019.

Kalogirou, S. A., The potential of solar industrial process heat applications, Applied Energy 76 pp. 337$361,2003$.

Kalogirou, S. A., Solar thermal collectors and applications, Progress in energy and combustion science 30 pp. 231-295, 2004.

Kalogirou, S. A., Solar Energy Engineering, Processes and Systems, Second Edition, Academic Press, The Boulevard, Langford Lane, Kidlington, Oxford, OX5 1GB, UK, 2014.

Kesraoui, M., Lazizi, A., and Chaib, A., Grid connected solar PV system: modelling, simulation and experimental tests, Energy Procedia 95 pp181-188, 2016.

Kreith, F., Manglik, R., M., Bohn, M. S., Principles of Heat Transfer Seventh Edition, Cengage Learning, 200 First Stamford Place, Suite 400, Stamford, CT 06902, USA, 2011.

Madanhire, I., Chiwarange, T., and Mbohwa, C., Design of Hybrid Solar Tobacco Curing System for Small Scale Farmers in Zimbabwe, Proceedings of the International Conference on Industrial and Operations Management, Bandug, Indonesia, March 6-8, 2018, pp. 2784-2795, 2018.

Manyanhaire, I. O., and Kurangwa, W., "Estimation of the impact of tobacco curing on wood resources in Zimbabwe", International Journal of Development and Sustainability, Vol.3 No7, pp. 1455-1467, 2014.

Mapfumo P., Chikowo, R., Mtambanengwe P., Lack of resilience in African smallholder farming: Exploring measures to enhance the adaptive capacity of local communities to pressures of climate change. A Project Final Technical Report Submitted to the International Development Research Centre (IDRC) Climate Change Adaptation in Africa (CCAA) Program, 2010.

Martelli, A. (2020) Environmental education with urban tree planting in order to neutralize greenhouse gasses, South Florid Journal for Development, Miami, v.1, n.1, 2-10, ISSN 2675-5459.

Mohseni-Languri, E., Taherani, H., Massodi, R. and Reisel, J.R., AN ENERGY AND EXERGY STUDY OF A SOLAR THERMAL AIR COLLECTOR, THERMAL SCIENCE: Vol. 13 No. 1, pp. 205-216, 2009.

Murwira, A., Unpublished. Climate Change in Zimbabwe: Opportunities for Adaptation and Mitigation Through Africa. Biocarbon Initiative Draft Report Submitted, n.d.

Murwira, A., Masocha, M., Gwitira, I., Shekede, M.D., Manatsa, D., Mugandhani, R., Unpublished. Zimbabwe Vulnerability and adaptation assessment. Draft Report, n.d.

Mussa, B.U., Kalli, B.M., Sadiq, M.G., and Tijjani, B.U., Modelling and Analysis of Hybrid Solar/wind Power System for a Small community, IOSR Journal of Electrical and Electronics Engineering (IOSRJEEE), e-ISSN: 2278-1676, p-ISSN: 2320-3331, Volume 10, Issue 1, Version 1, pp. 39-45, Jan-Feb 2015. 
Musoni, S., Nazare, R., Manzungu, E., and Chekenya, B., REDESIGN OF COMMONLY USED TOBACCO CURING BARNS IN ZIMBABWE FOR INCREASED ENERGY EFFICIENCY, International Journal of Engineering Science and Technology (IJEST), Vol. 5 No.3, 2013.

Oguz, Y., and Ozsoy, M.F. Sizing, design and installation of an isolated wind-photovoltaic hybrid power system with battery storage for a laboratory general illumination in Afyonkarahisar, Turkey, Journal of Energy in Southern Africa, Volume 26 Number 4, pp. 70-80, 2015.

Saini, P., Patil, D., V., and Powar, S., Review on Integration of Solar Air Heaters with Thermal Energy Storage, Researchgate, Available: http://www.researchgate.net/publication/321396089, April 14, 2019, 2018.

Saint, R. M., Garnier, C., Pomponi, F., and Curie J. (2018) Thermal Performance through Heat Retention in Integrated Collector-Storage Solar Water Heaters: Review. Energies, 11, 1615, 2018.

Sumner, P.E., and Moore, M.J., Harvesting and Curing Flue-Cured Tobacco, The University of Georgia Cooperative Extension, Bulletin 884, pp. 1-16, Reviewed June 2009.

Syafaruddin and Hiyama, T., Lecture 4: Heat Utilisation, Available: http://www.cs.kumamotou.ac.jp/APSF/, March 3, 2020.

Tobacco Industry and Marketing Board, TIMB. Annual Statistical Report, 2010.

United Nations Development Programme, UNDP. Solar Water Heating Training Manual for the Kenyan Industry, Available: https://www.ke.undp.org>docs>energy_and_environment.pdf, September 11, 2020, 2017.

World Bank, Solar resource maps of Zimbabwe, Global Solar Atlas 2.0, Global horizontal irradiation, 2019. Solargis, Available: https://www.solargis.com/maps-and-gis-data/download/zimbabwe, 20 September, 2020.

Zhou, W., Lou, C.Z., Li, Z.S., Lu, L., and Yang, H.X. (2010) Current status of research on optimum sizing of stand-alone solar-wind power generation systems, Applied Energy 87, pp. 380-389, 2010. 